\title{
PENINGKATAN PENGETAHUAN DAN KEPATUHAN MELAKUKAN KEBERSIHAN TANGAN MELALUI PELATIHAN DENGAN FLUORESCENCE LOTION
}

\author{
Grace Solely ${ }^{1,2^{*}}$, Hanny Handiyani ${ }^{3}$, Tuti Nuraini ${ }^{3}$ \\ 1. Fakultas Ilmu Keperawatan, Universitas Pelita Harapan \\ 2. Program Studi Magister Fakultas Ilmu Keperawatan, Universitas Indonesia, Depok 16424, Indonesia \\ 3. Fakultas Ilmu Keperawatan, Universitas Indonesia, Depok 16424, Indonesia \\ "E-mail: gracesolely@yahoo.com
}

\begin{abstract}
Abstrak
Kebersihan tangan dapat mencegah Health Care Associated Infections (HAIs) dan meningkatkan keselamatan pasien. Penggunaan fluorescence lotion pada pelatihan kebersihan tangan merupakan metode pembelajaran dengan menggunakan experiential learning yang bertujuan untuk meningkatkan pengetahuan dan kepatuhan perawat dalam kebersihan tangan. Tujuan penelitian ini untuk mengidentifikasi pengaruh program pelatihan kebersihan tangan terhadap pengetahuan dan kepatuhan perawat dalam kebersihan tangan. Rancangan penelitian ini menggunakan pendekatan quasy experiment dengan metode pre test-post test designs with comparison group. Sampel dalam penelitian adalah 32 perawat pelaksana untuk kelompok intervensi dan 38 perawat pelaksana untuk kelompok kontrol. Hasil penelitian menunjukkan terdapat perbedaan pengetahuan dan kepatuhan kebersihan tangan antara kelompok eksperimen dan kelompok kontrol setelah pelatihan kebersihan tangan $(p<0,001$, CI pengetahuan $=2,061 ; 3,541$, CI kepatuhan $=6,792 ; 10,929)$. Pelatihan kebersihan tangan perlu dilakukan berkesinambungan.
\end{abstract}

Kata kunci: fluorescence lotion, kebersihan, kepatuhan, pelatihan, pengetahuan, tangan.

\begin{abstract}
Fluorescence Lotion Training Increases Knowledge and Conformity in Hand Hygiene. Hand hygiene prevents Health-Care-Associated Infections (HAIs) and improves patient safety. The use of fluorescence lotion in hand hygiene training is the implementation of a learning method that use experiential learning to improve the level of knowledge and conformity of nurses in maintaining hand hygiene. The research objective is to identify the influence of hand hygiene training program on the level of knowledge and conformity of nurses in maintaining hand hygiene. The research is quasy experiment research using pretest-posttest design with comparison group. The research sample consists of 32 nurses in experiment group and 38 nurses in control group. The result showed a difference in the knowledge after hand hygiene training was conducted ( $p<0,001$, CI knowledge $=2,061 ; 3,541$, CI conformity $=6,792$; $10,929)$ between those in the control group and those in the experiment group. It is recommended to sustainably conduct hand hygiene training program.
\end{abstract}

Keywords: conformity, fluorescence lotion, hand hygiene, knowledge, training.

\section{Pendahuluan}

Kepatuhan dalam kebersihan tangan (KT) yang benar mutlak dilakukan oleh perawat sehingga praktik KT dapat dilakukan pada setiap tindakan keperawatan. KT merupakan faktor utama dan penting dalam mencegah penyebaran patogen dan resisten antibiotik di rumah sakit karena jumlah infeksi yang dapat ditransmisikan melalui tangan tim kesehatan sangat banyak. KT dapat mencegah Health Care Associated Infections
(HAIs) dan meningkatkan keselamatan pasien. KT merupakan bagian dari kewaspadaan standar yang dapat menurunkan infeksi pada tim kesehatan dan juga pasien (CDC, 2010).

Program KT perawat dapat berhasil apabila pengetahuan dan kepatuhan perawat juga baik. Kepatuhan KT menurunkan angka insiden HAIs (dari 11 menjadi 8,2 per 1000 pasien per hari) dan $60 \%$ adanya penurunan risiko HAIs pada neonatal (Silva, et al., 2004; WHO, 2009a; WHO, 
2009b). Kepatuhan KT secara signifikan menurunkan MRSA bakterimia, yaitu dari 0,03/100 pasien pulang menjadi $0,01 / 100$ pasien pulang selama 1 bulan (Grayson, et al., 2008; WHO, 2009a; WHO, 2009b).

Kompetensi perawat terkait dengan KT akan meningkat dengan meningkatnya pengetahuan, praktik, dan perilaku perawat. Hasil penelitian menunjukkan bahwa program pendidikan yang efektif dapat meningkatkan pengetahuan, perilaku positif, praktik yang tepat dalam menjalankan kebijakan pencegahan, dan pengendalian infeksi (Madrazo, et al., 2009) menyatakan bahwa tim kesehatan memerlukan informasi dan pendidikan yang lebih banyak tentang pencegahan dan pengendalian infeksi khususnya tentang KT sehingga akan meningkatkan kualitas pelayanan kesehatan (Rajcevic, Djuric, Grujicic, Dugandzija, \& Cosic, 2012). Ketidakpatuhan terhadap KT merupakan suatu perilaku yang buruk dan dapat dikontrol dengan melakukan pelatihan (Fitzpatrick, et al., 2011).

Experiential learning adalah teori pembelajaran yang dapat digunakan di dalam pelatihan kebersihan tangan karena peserta didik dibimbing untuk melakukan langsung keterampilan kebersihan tangan (learning by doing). Hasil penelitian Berg, Sultana, Sorokin, Kairys, Vergare, dan Berg (2008) menunjukkan bahwa KT dengan menggunakan ceramah, video tentang indikasi, teknik melakukan $\mathrm{KT}$, dan simulasi dengan menggunakan fluoresence lotion meningkatkan pengetahuan residen menjadi $78 \%$ dan hasil observasi menunjukkan bahwa kepatuhan residen meningkat menjadi $65 \%$. Hasil penelitian ini dapat menjadi acuan untuk melakukan penelitian yang serupa di Indonesia karena masih kurangnya kepatuhan tenaga kesehatan khususnya perawat untuk melakukan cuci tangan.

Simarmata (2009) menyatakan bahwa alasan dilakukannya proyek pelatihan, evaluasi, umpan balik, dan reminder KT di tiga rumah sakit swasta di Indonesia karena tidak konsistennya perilaku mencuci tangan oleh tim kesehatan pada saat sebelum dan sesudah melakukan tindakan, khususnya apabila staf menyentuh lingkungan di sekitar pasien yang meningkatkan potensial risiko transmisi infeksi. Pengetahuan dan kepatuhan KT di rumah sakit belum baik. Hasil observasi kepatuhan KT menunjukkan bahwa 10 perawat yang di observasi belum melakukan praktik KT yang benar menurut WHO. Kepala seksi keperawatan rumah sakit menyatakan bahwa sampai dengan saat ini belum ada pelatihan KT yang spesifik.

\section{Metode}

Desain penelitian yang digunakan dalam penelitian ini adalah kuasi eksperimen dengan pendekatan pre test-post test with control group design yang melibatkan experiment treatment dari dua kelompok subjek (Polit \& Beck, 2009). Tujuan penelitian ini adalah untuk mengukur pengaruh program pelatihan KT dengan fluorscence lotion terhadap pengetahuan dan kepatuhan perawat dalam KT. Variabel independen adalah program pelatihan KT dengan alat fluorescence lotion dan variabel dependen adalah pengetahuan dan kepatuhan perawat tentang KT.

Teknik pengambilan sampel dalam penelitian ini adalah total sampling perawat pelaksana di RS S. Sampel yang didapatkan dari kelompok eksperimen berjumlah 32 orang dan 38 orang untuk kelompok kontrol.

Penelitian ini sudah melalui uji etik di Fakultas Ilmu Keperawatan UI. Penelitian ini menggunakan prinsip utama etik (Polit \& Beck, 2009). Peneliti melindungi responden dari bahaya fisik maupun psikologis. Responden ditemui oleh peneliti dengan didampingi oleh kepala ruang kemudian peneliti menjelaskan tujuan dan manfaat penelitian. Peneliti menjamin fluorescence lotion yang digunakan pada penelitian ini aman dan tidak menimbulkan alergi pada kulit tangan responden. Responden diberikan kesempatan untuk memberikan pertanyaan. Peneliti memberikan informed consent kepada responden setelah diberikan informasi dan penjelasan tentang penelitian.

Instrumen yang digunakan pada penelitian ini adalah kuesioner A, B, C, dan instrumen observasi D. Kuesioner A untuk mendapatkan data karakteristik perawat pelaksana yang terdiri 
atas usia, jenis kelamin, tingkat pendidikan, dan masa kerja. Kuesioner B dan C dikembangkan dalam bentuk pertanyaan untuk mengukur tingkat pengetahuan perawat sebelum dan setelah intervensi. Instrumen D adalah lembar observasi untuk melihat kepatuhan perawat sebelum dan setelah intervensi. Intervensi pelatihan menggunakan modul program pelatihan KT simulasi dengan alat fluorescence lotion dan lampu $U V$ Light BLB 10 watt. Pembelajaran menggunakan metode ceramah, diskusi, video, demonstrasi, dan didemonstrasikan kembali. Pelatihan ini hanya diberikan pada kelompok eksperimen. Kelompok kontrol tidak diberikan intervensi.

Analisis data dilakukan dengan analisis univariat dan bivariat. Uji kesetaraan karakteristik responden yaitu: umur, jenis kelamin, tingkat pendidikan, masa kerja, dan pelatihan KT menggunakan uji Chi-Square. Analisis perbedaan pengetahuan dan kepatuhan perawat tentang KT sebelum dan sesudah intervensi antara kelompok eksperimen dan kontrol menggunakan uji Mann-Whitney karena data berdistribusi tidak normal.

\section{Hasil}

Pengamatan langsung dilakukan pada kelompok eksperimen dan kelompok kontrol. Pengamatan dilakukan sampai dengan 200 kesempatan dalam melakukan kebersihan tangan pada masing-masing kelompok (Tabel 1). Kesetaraan karakteristik perawat pelaksana pada kelompok eksperimen dengan kelompok kontrol dapat dilihat pada Tabel 2. Setelah intervensi, dengan menggunakan uji Mann-Whitney, terlihat perbedaan yang bermakna pada pengetahuan dan tingkat kepatuhan perawat pelaksana kelompok eksperimen dan kelompok kontrol (Tabel 3 dan 4). Pengetahuan kelompok eksperimen lebih tinggi tiga poin dibandingkan dengan kelompok kontrol. Kepatuhan kelompok eksperimen lebih tinggi 8 poin dibanding kelompok kontrol.

\section{Pembahasan}

Hasil univariat memberikan gambaran bahwa umur perawat pelaksana kelompok eksperimen dan kelompok kontrol mayoritas adalah diatas dan sama dengan 32 tahun. Bastable (2008) menjelaskan bahwa kemampuan fisik pada rentang usia 20-40 tahun berada pada tingkat tinggi karena tubuh dapat berfungsi secara optimal, mayoritas keterampilan psikomotorik dapat dilakukan pada rentang usia ini. Penelitian Yulia (2010) menunjukkan bahwa tidak ada hubungan yang signifikan antara umur dan pemahaman perawat pelaksana pada kelompok eksperimen dengan $\mathrm{p}=0,460$ dan tidak adanya hubungan signifikan antara umur dan pemahaman perawat pelaksana pada kelompok kontrol dengan $p=0,373$. Analisis peneliti terkait dengan hal ini bahwa kemampuan kognitif tidak dapat hanya dikaitkan dengan faktor pertambahan umur tetapi variasi individual dari luas pengetahuan, banyaknya keterampilan, kapasitas memori yang bekerja, dan kecepatan memproses memori.

Mayoritas jenis kelamin pada kelompok eksperimen dan kontrol adalah perempuan sebanyak 56 orang $(80 \%)$. Pria dan wanita memiliki perbedaan di dalam bertindak dan bereaksi di dalam setiap aspek kehidupan (Cahill, 2007; Bastable, 2008). Hasil penelitian menyatakan bahwa tidak ada perbedaan di dalam proses pembelajaran antara pria dan wanita (Tumkaya, 2012). Jenis kelamin tidak memberikan pengaruh terhadap peningkatan pengetahuan dan kepatuhan perawat pelaksana dalam melakukan KT.

Tingkat pendidikan pada kelompok eksperimen dan kontrol secara keseluruhan adalah vokasional sebanyak 63 orang (90\%). Penelitian tentang attitudes toward and knowledge of affirmative action in higher education menunjukkan bahwa umur, jenis kelamin, dan tingkat pendidikan tidak memberikan pengaruh yang signifikan terhadap pengetahuan dan sikap seseorang (Carr, 2007). Peningkatan pengetahuan dan kepatuhan perawat pelaksana dalam melakukan KT tidak hanya dipengaruhi oleh tingkat pendidikan.

Mayoritas masa kerja pada kelompok eksperimen dan kontrol diatas 1 tahun sebanyak 65 orang $(92,9 \%)$. Seseorang yang sudah lama bekerja dengan pengalaman yang lebih banyak akan lebih baik dalam melakukan pekerjaannya. Semakin lama seseorang di pelayanan klinis 
Tabel 1. Hasil Observasi Perilaku Kepatuhan Kebersihan Tangan pada Kelompok Eksperimen dan Kelompok Kontrol Setelah Pelatihan Kebersihan Tangan dengan Fluorescence Lotion

\begin{tabular}{lcccccc}
\hline \multirow{2}{*}{ Variabel } & \multicolumn{2}{c}{ Kelompok } & \multicolumn{2}{c}{ Kelompok Kontrol } & \multicolumn{2}{c}{ Total } \\
\cline { 2 - 7 } & $\mathbf{n}$ & $\mathbf{\%}$ & $\mathbf{n}$ & $\mathbf{\%}$ & $\mathbf{n}$ & $\mathbf{\%}$ \\
\hline Perilaku Kepatuhan KT (Post Test) & & & & & & \\
Patuh & 61 & 30,5 & 12 & 6 & 73 & 18,25 \\
Tidak Patuh & 139 & 69,5 & 188 & 94 & 327 & 81,75 \\
Total & 200 & 100 & 200 & 100 & 400 & 100 \\
\hline
\end{tabular}

Tabel 2. Analisis Kesetaraan Umur, Jenis Kelamin, Tingkat Pendidikan, Masa Kerja, dan Pelatihan KT Perawat Pelaksana pada Kelompok Eksperimen dan Kelompok Kontrol

\begin{tabular}{|c|c|c|c|c|c|c|}
\hline \multirow[t]{2}{*}{ Variabel } & \multicolumn{2}{|c|}{$\begin{array}{c}\text { Kelompok } \\
\text { Eksperimen }\end{array}$} & \multicolumn{2}{|c|}{ Kelompok Kontrol } & \multirow[t]{2}{*}{$\mathbf{p}$} & \multirow[t]{2}{*}{$95 \% \mathrm{CI}$} \\
\hline & $\mathbf{n}$ & $\%$ & $\mathrm{n}$ & $\%$ & & \\
\hline \multicolumn{7}{|l|}{ Umur } \\
\hline a. $\geq 32$ tahun & 19 & 40,6 & 19 & 50 & \multirow{3}{*}{0,587} & \multirow{3}{*}{0,$565 ; 3,778$} \\
\hline b. $<32$ tahun & 13 & 59,4 & 19 & 50 & & \\
\hline Total & 32 & 100 & 38 & 100 & & \\
\hline \multicolumn{7}{|l|}{ Jenis Kelamin } \\
\hline a. Laki-laki & 3 & 9,4 & 11 & 28,9 & \multirow{3}{*}{0,041} & \multirow{3}{*}{0,$991 ; 15,655$} \\
\hline b. Perempuan & 29 & 90,6 & 27 & 71,7 & & \\
\hline Total & 32 & 100 & 38 & 100 & & \\
\hline \multicolumn{7}{|l|}{ Tingkat Pendidikan } \\
\hline a. Vokasional & 30 & 93,7 & 33 & 86,8 & \multirow{3}{*}{0,442} & \multirow{3}{*}{0,$079 ; 2,439$} \\
\hline b. Profesional & 2 & 6,3 & 5 & 13,2 & & \\
\hline Total & 32 & 100 & 38 & 100 & & \\
\hline \multicolumn{7}{|l|}{ Masa Kerja } \\
\hline a. Diatas 1 tahun & 29 & 90,6 & 36 & 94,7 & \multirow{3}{*}{0,654} & \multirow{3}{*}{0,$084 ; 3,432$} \\
\hline b. Dibawah 1 tahun & 3 & 9,4 & 2 & 5,3 & & \\
\hline Total & 32 & 100 & 38 & 100 & & \\
\hline \multicolumn{7}{|l|}{ Mengikuti Pelatihan } \\
\hline a. Pernah & 9 & 28,1 & 12 & 31,6 & \multirow{3}{*}{0,958} & \multirow{3}{*}{0,$303 ; 2,376$} \\
\hline b. Tidak Pernah & 23 & 71,9 & 26 & 68,4 & & \\
\hline Total & 32 & 100 & 38 & 100 & & \\
\hline
\end{tabular}

Tabel 3. Perbedaan Pengetahuan Perawat Pelaksana pada Kelompok Eksperimen dan Kelompok Kontrol menurut Pengukuran II (Post Test)

\begin{tabular}{lccccc}
\hline \multicolumn{1}{c}{ Variabel } & n & $\begin{array}{c}\text { Median }( \\
\text { minimum-maksimum) }\end{array}$ & Rerata \pm s.b. & CI 95\% & p \\
\hline Pengetahuan (0-20) & & & & & \\
Kelompok Eksperimen & 32 & $16(13-19)$ & $15,91 \pm 1,329$ & $2,061-3,541$ & $<0,001$ \\
Kelompok Kontrol & 38 & $13(8-17)$ & $13,11 \pm 1,705$ & & \\
\hline
\end{tabular}


Tabel 4. Perbedaan Kepatuhan Perawat Pelaksana pada Kelompok Eksperimen dan Kelompok Kontrol menurut Pengukuran II (Post Test)

\begin{tabular}{lccccc}
\hline \multicolumn{1}{c}{ Variabel } & n & $\begin{array}{c}\text { Median } \\
\text { (minimum-maksimum) }\end{array}$ & Rerata \pm s.b. & CI 95\% & p \\
\hline Kepatuhan (15-60) & & & & & \\
Kelompok Eksperimen & 32 & $49(43-59)$ & $50,28 \pm 5,050$ & $6,792-10,929$ & $<0,001$ \\
Kelompok Kontrol & 38 & $41(31-48)$ & $41,42 \pm 3,168$ & \\
\hline
\end{tabular}

maka akan semakin baik penampilan klinis seseorang tersebut (Swansburg, 2002). Semakin lama orang bekerja akan semakin berpengalaman dalam menghadapi masalah yang ada, akan tetapi belum tentu juga seorang individu yang lama bekerja lebih produktif dibandingkan dengan yang baru bekerja (Robbins, 2006). Masa kerja tidak selalu dapat dihubungkan dengan pengetahuan dan kepatuhan, perlu adanya pelatihan KT yang berkesinambungan sehingga perawat pelaksana akan mengingat dan melakukan informasi yang didapatkan.

Sebagian besar perawat pelaksana pada kelompok eksperimen dan kelompok kontrol tidak pernah mengikuti pelatihan kebersihan tangan, yaitu 49 orang (70\%). Pemberian informasi kepada perawat pelaksana tentang KT sangat diperlukan. Perawat pelaksana yang tidak memiliki pengetahuan KT akan sulit untuk memiliki perilaku yang baik tentang kepatuhan KT.

Hasil penelitian ini menunjukkan perbedaan pengetahuan perawat pelaksana tentang kebersihan tangan setelah mendapatkan pelatihan kebersihan tangan dengan fluorescence lotion pada kelompok eksperimen dan kelompok kontrol. Pelatihan kebersihan tangan diperlukan untuk melakukan perubahan perilaku perawat dalam kepatuhan KT. Selain itu, dalam poin evaluasi dan umpan balik akan dilakukan survei terhadap pengetahuan perawat tentang KT. Pelatihan yang teratur tentang pentingnya KT berdasarkan pendekatan "my 5 moments for hand hygiene" dan teknik yang tepat untuk melakukan handrubbing dan handwashing kepada tenaga kesehatan termasuk perawat sangat diperlukan (WHO, 2009; CDC, 2010). Perhatian terhadap pendidikan kebersihan tangan di dalam kurikulum pendidikan sangat penting karena pengetahuan dan keterampilan siswa ini akan memengaruhi kepatuhan kebersihan tangan mereka pada saat praktik klinik (Grayling \& Stevenson, 2006; Kelcíkova, Skodova, \& Straka, 2012).

Hasil penelitian menunjukkan adanya perbedaan kepatuhan perawat pelaksana tentang kebersihan tangan setelah mendapatkan pelatihan kebersihan tangan dengan Fluorescence Lotion pada kelompok eksperimen dan kelompok kontrol. Peningkatan kualitas praktik kebersihan tangan pada perawat dapat dilakukan dengan memberikan pelatihan tentang bentuk tindakan perawatan pasien yang dapat menyebabkan kontaminasi pada tangan dan keuntungan dan kerugian dari berbagai metode dalam kebersihan tangan (Parini, 2004). Kepatuhan tenaga kesehatan dalam melakukan kebersihan tangan harus selalu di monitor dan setiap individu diberikan umpan balik terkait dengan praktik kebersihan tangan (Pittet, et al., 2004).

Hasil penelitian yang menunjukkan perbedaan yang signifikan ini tidak terlepas dari intervensi yang berbeda dari intervensi pelatihan yang biasa. Pelatihan yang dipakai dalam intervensi ini menggunakan model experiental learning. Beberapa penelitian mendukung model experiental learning digunakan dalam model pembelajaran. (Szilagyi, et al., 2013; Abdulwahed \& Nagy, 2009; Kolb \& Kolb, 2005). Model pembelajaran experiential learning memberikan 4 pencapaian tujuan pembelajaran yaitu memperkenalkan peserta didik pada konseptual, teoritikal, dan metodologi mata ajar, meningkatkan kesadaran peserta didik tentang topik yang spesifik, menciptakan hubungan yang lebih kuat antara peserta didik dan komunitas, membantu peserta didik untuk memahami rangkaian kesatuan antara teori, praktik, dan kebijakan (Rone, 2008). 
Pelatihan dengan menggunakan experiential learning memberikan kesempatan kepada peserta didik bukan sebagai pendengar yang aktif tetapi sebagai peserta yang aktif untuk berpartisipasi di dalam proses pembelajaran. Hasil penelitian ini menunjukkan bahwa program pelatihan dengan fluorescence lotion memberikan pengaruh yang positif terhadap pengetahuan dan menciptakan persepsi yang positif pada perawat pelaksana di dalam melakukan kebersihan tangan. Pelatihan merupakan salah satu cara untuk mempelajari kebersihan tangan karena dapat mentransformasi pengetahuan ke dalam tingkah laku dan peserta pelatihan akan menyimpan informasi yang didapatkan.

Pembelajaran experiential learning harus berfokus pada peserta didik. Tenaga pengajar harus memiliki komitmen dan integritas untuk memastikan bahwa program pendidikan berpusat pada peserta didik. Peserta didik harus dilibatkan di dalam proses pengajaran (Estes, 2004). Hasil penelitian Niemantsverdriet, Van der Vleuten, Majoor, dan Scherpbier (2005) menyatakan bahwa experiential learning memberikan hasil pencapaian yang positif dan bernilai pada peserta didik. Keeton, Sheckley, dan Griggs (2002) menyatakan bahwa dengan mengembangkan keefektifan sebagai seorang peserta didik, peserta didik dapat memberdayakan tanggung jawab dari proses pembelajaran melalui pengalaman. Pengalaman merupakan cara terbaik untuk belajar dan meningkatkan keterampilan yang diperlukan.

Pelatihan dengan cara tradisional tidak akan dapat memberikan pengaruh yang signifikan terhadap kepatuhan kebersihan tangan. Perlu adanya program pendidikan pelatihan yang lebih komprehensif yang dapat meningkatkan motivasi staf untuk melakukan kebersihan tangan sehingga kebersihan tangan menjadi tingkah laku yang permanen. Pelatihan kebersihan tangan dengan fluorescence lotion dapat meningkatkan motivasi dan rasa antusias peserta didik sehingga akan meningkatkan kepatuhan staf di dalam melakukan kebersihan tangan. Pihak manajemen juga harus memberikan dukungan untuk menyukseskan program kebersihan tangan.
Yeganeh dan Kolb (2009) menyatakan bahwa teori experiential learning memiliki pengaruh yang sangat besar terhadap perkembangan kepemimpinan dan organisasi. Peningkatan kualitas kebersihan tangan dapat dilakukan dengan menyediakan alternatif cairan pembersih tangan bagi kulit tangan tenaga kesehatan yang alergi, program pelatihan, motivasi, dan dukungan manajemen (Akyol, 2007).

Pelatihan kebersihan tangan merupakan salah satu fungsi pengarahan dari fungsi manajemen (Marquis \& Huston, 2010). Spouse (2003) menyatakan bahwa melakukan fungsi pengarahan pada fungsi manajemen adalah dengan melakukan supervisi yang baik dari seorang mentor sehingga kemampuan seseorang di dalam memberikan tindakan keperawatan akan meningkat. Kegiatan yang dapat dilakukan pada fungsi manajemen adalah melakukan pelatihan kebersihan tangan dengan fluorescence lotion, memberikan motivasi, bimbingan dan arahan, melakukan monitoring kepatuhan kebersihan tangan, dan memberikan umpan balik dari hasil monitoring tersebut.

Fungsi pengarahan pada fungsi manajemen berkaitan dengan pelatihan kebersihan tangan yang dilakukan. Fungsi pengarahan yang berkaitan dengan kebersihan tangan dapat diberikan dengan memberikan motivasi kepada para perawat, membantu untuk selalu memperbaharui keterampilan sesuai dengan visi dan misi rumah sakit, menjadi mentor bagi perawat pada saat memberikan bimbingan dan arahan (Wilson-Barnett, et al. 1995). Manajemen rumah sakit perlu memberikan dukungan untuk menyukseskan program kebersihan tangan.

Hasil penelitian menunjukkan perbedaan yang signifikan pengetahuan dan kepatuhan perawat pelaksana tentang kebersihan tangan antara kelompok eksperimen dan kelompok kontrol. Rumah sakit dapat menggunakan modul pelatihan dan hasil yang didapatkan dari penelitian ini sebagai dasar untuk mengembangkan program pelatihan kebersihan tangan baik bagi perawat maupun profesi yang lain.

Perawat pelaksana yang diberikan pelatihan kebersihan tangan dengan fluorescence lotion 
lebih memiliki rasa keingintahuan, antusias dan kesadaran yang tinggi tentang pentingnya melakukan kebersihan tangan karena melakukan dan melihat langsung (learning by doing). Perawat lebih terbuka untuk memberikan pendapatnya pada saat diskusi.

Hasil penelitian yang diperoleh dapat digunakan sebagai bahan kajian yang bermanfaat dalam mengembangkan pengalaman belajar peserta didik dengan menggunakan teori experiential learning dengan metode pembelajaran demonstrasi dan didemonstrasikan kembali sehingga informasi yang didapatkan oleh peserta didik akan dilakukan pada ruang lingkup praktik klinik. Penelitian ini menghasilkan sejumlah data yang dapat digunakan untuk mengembangkan penelitian lebih lanjut dengan desain yang berbeda baik secara kuantitatif maupun kualitatif. Penelitian ini dapat menjadi dasar untuk mengembangkan metode pembelajaran yang tepat untuk meningkatkan motivasi dan kinerja perawat dalam melakukan kebersihan tangan.

\section{Kesimpulan}

Hasil penelitian menunjukkan terdapat perbedaan yang signifikan pada pengetahuan dan kepatuhan antara kelompok eksperimen dan kelompok kontrol setelah dilakukan pelatihan KT dengan fluorescence lotion. Direktur rumah sakit sebaiknya merumuskan dan mengembangkan kebijakan khususnya tentang kebersihan tangan dan merencanakan anggaran untuk program kebersihan tangan. Manajemen keperawatan untuk melakukan pelatihan kebersihan tangan dengan fluorescence lotion dengan melibatkan Infection Prevention Control Nurse (IPCN). IPCN dan kepala ruang melakukan observasi kebersihan tangan dan memberikan umpan balik. Peneliti lain diharapkan dapat mengembangkan penelitian dengan desain kualitatif yang dapat menggali berbagai fenomena lebih mendalam khususnya tentang persepsi dan pengalaman terkait dengan kebersihan tangan (MS, TN, AR)

\section{Referensi}

Abdulwahed, M., \& Nagy, Z.K. (2009). Applying Kolb's experiential learning cycle for laboratory education. Journal of Engineering Education, 98(3), 283-294.

Akyol, A.D. (2007). Hand hygiene among nurses in Turkey: Opinions and practices. Journal Of Clinical Nursing, 16(3), 431-437. Doi: 10.1111/ j.1365 2702.2005.01543.x.

Bastable, S.B. (2008). Nurse as educator: Principles of teaching and learning for nursing practice (3rd Ed.). Sudbury, Mass: Jones and Bartlett Publisher.

Berg, K., Sultana C., Sorokin R., Kairys, J., Vergare, M., \& Berg, D. (2008). A novel curriculum using simulation to teach and assess indications and technique of handwashing to GME learners. Philadelphia: Thomas Jhonson Univeristy.

Cahill, L. (2006). Why sex matter in neurosciences. Nature Review Neuroscience, 7, 477- 484. Doi:10.1038/nrn1909.

Carr, E.A. (2007). Attitudes toward and knowledge of affirmative action in higher education. Western Michigan University. Diperoleh dari http://scholarworks.wmich.edu/dissertations/8 $41 /$

Centers for Disease Control \& Prevention (CDC). (2010). Hand hygiene infection control. Diperoleh dari http://www.cdc.gov/handhygiene/.

Estes, C.A. (2004). Promoting student-centered learning in experiential education. Journal of Experiential Education, 27(2), 141-160.

Fitzpatrick, M., Everett-Thomas, R., Nevo, I., Shekhter, I., Rosen, L.F., Scheinman, S.R., Arheart, K.L., \& Birnbach, D.J. (2011). A novel educational programme to improve knowledge regarding health care-associated infection and hand hygiene. International Journal of Nursing Practice, 17(3), 269-274. doi: 10.1111/j.1440-172X.2011.01934.x. 
Grayling, I., \& Stevenson, K. (2006). A trainer's perspective. in workplace bullying in the nhs (Randle J. Ed.). Radcliffe Press: Oxford.

Grayson, M.L., Jarvie, L.J., Martin, R., Johnson, P.D.R., Jodoin, M.E., McMullan, C., Gregory, R.H.C., Bellis, K., Cunnington, K., Wilson, F.L., Quin, D., \& Kelly, A.M. (2008). Significant reductions in methicillin-resistant Staphylococcus aureus bacteraemia and clinical isolates associated with a multisite, hand hygiene culture-change program and subsequent successful statewide roll-out. Medical Journal of Australia. 188 (11), 633-640.

Keeton, M.T., Sheckley, B.G., \& Griggs, J.K. (2002). Efficiency and effectiveness in higher education. Dubuque, IA: Kendall/ Hunt Publishing Company.

Kelcíkova, S., Skodova, Z., \& Straka, S. (2012). Effectiveness of hand hygiene education in a basic nursing school curricula. Public Health Nursing, 29(2), 152-159. Doi: 10.1111/j.15251446.2011.00985.x.

Kolb, A.Y., \& Kolb, D.A. (2005). Learning styles and learning spaces: Enhancing experiential learning in higher education. Academy of Management Learning \& Education, 4(2), 193-212. Doi: 10.5465/AMLE.2005.17268566.

Marquis, B.L., \& Huston, C.J. (2010). Kepemimpinan dan manajemen keperawatan: teori \& aplikasi (4th Ed.) (Widyawati Penerj.). Philadelphia: Lippincott.

Madrazo, C.M., Dorado, A.C., Fort, M.A.S., Herranz, J.C.A., Selfa, R.A., Ferradal, I.G., Matorral, F.E., Pau, C.E., \& Diaz, S.S. (2009). Effectiveness of a training programme to improve hand hygiene compliance in primary healthcare. BMC Public Health, 9469-9476. Doi: 10.1186/1471-2458-9-469.

Niemantsverdriet, S., Van derVleuten, C.M., Majoor, G.D., \& Scherpbier, A.A. (2005). An explorative study into learning on international traineeships: Experiential learning processes dominate. Medical Education, 39(12), 1236-1242. Doi: 10.1111/j.1365-2929.2005.02114.x.

Parini, S.M. (2004). Know your hand in hygiene. Nurse Management, 35, 12-15.
Silva, C.L.P., Dharan S., Hugonnet S., Touveneau, S., Barbe, K.P., Pfister, R., \& Pittet D. (2004). Dynamics of bacterial hand contamination during routine neonatal care. Infection Control and Hospital Epidemiology, 25(03), 192-197.

Pittet, D., Simon, A., Hugonnet, S., Silva, C.L.P., Sauvan, V., \& Perneger, T.V. (2004) Hand hygiene among phycians: Performance, beliefs, and perceptions. Annals Internal Medicine, 141(1), 1-8. Doi: 10.7326/00034819-141-1-200407060-00008.

Polit, F.D., \& Beck, C.T. (2009). Essentials of nursing research (7th Ed.). Philadelphia: Lippincott Williams \& Wilkins.

Rajcevic, S., Djuric, P., Grujicic, M., Dugandzija, T., \& Cosic, G. (2012). Knowledge, habits, and attitudes of health care workers about hand hygiene. Healthmed, 6(4), 1418-1423.

Robbins, S.P. (2006). Perilaku organisasi (Benyamin Molan, Penerj.). Jakarta: Gramedia.

Rone, T.R. (2008). Culture from the outside in and the inside out: Experiential education and the continuum of theory, practice, and policy. College Teaching, 56(4), 237-246.

Simarmata, R. (2009). Clean care is safer care WHO case study. Diperoleh dari http://www. who.int/gpsc/5may/share/case_study_ramsay_ health_care_indonesia/en/index.html.

Spouse, J. (2003). Professional learning in nursing. Oxford: Blackwell Science.

Swansburg, R.C. (2002). Management and leadership for nurse manager. United States of America: Jones and Bartlett.

Szilágyi, L., Haidegger, T., Lehotsky, Á., Nagy, M., Csonka, E.A., Sun, X., Ooi, K.L., \& Fisher, D. (2013). A large-scale assessment of hand hygiene quality and the effectiveness of the "WHO 6-steps". BMC Infectious Diseases, 13(1), 1-10. Doi: 10.1186/1471-2334-13-249.

Tumkaya, S. (2012). The Investigation of the epistemological beliefs of university students according to gender, grade, fields of study, academic success and their learning styles. 
Educational Sciences: Theory \& Practice, 12(1), 88-95.

Wilson-Barnett J., Butterworth, T., \& White, E., (1995). Clinical support and the project 2000 nursing student: Factors influencing this process. Journal of Advanced Nursing. 21, $1152-1158$.

World Health Organization. (2009a). WHO Multi modal hand hygiene strategy. Geneva, Switzerland: World Health Organization Press.

World Health Organization. (2009b). Hand hygiene technical reference manual. Geneva,
Switzerland: World Health Organization Press.

Yeganeh, B., \& Kolb, D. (2009). Mindfulness and Experiential Learning. OD Practitioner, 41(3), 13-18.

Yulia, S. (2010). Pengaruh pelatihan keselamatan pasien terhadap pemahaman perawat pelaksana mengenai penerapan keselamatan pasien di RS Tugu Ibu Depok. (Tesis magister, tidak dipublikaskan) Fakultas Ilmu Keperawatan, Universitas Indonesia, Depok, Jawa Barat 